\title{
MATERNAL CHARACTERISTICS AND COMPLEMENTARY FEEDING FOR CHILDREN UNDER 2 YEARS OLD: A CORRELATION STUDY IN TLATAH VILLAGE, PURWOSARI, BOJONEGORO
}

Karakteristik Ibu dan Pemberian MPASI pada Anak dibawah 2 Tahun: Studi Korelasi di Desa Tlatah, Purwosari, Bojonegoro

\author{
Resawati Intan Savitri ${ }^{1}$, Dani Nasirul Haqi ${ }^{1}$ \\ ${ }^{1}$ Faculty of Public Health, Universitas Airlangga \\ resawati.intan.savitri-2017@fkm.unair.ac.id
}

ARTICLE INFO
Article History:
Received:
November, $23^{\text {th }}, 2020$
Revised:
From January, $1^{\text {st }}$,
2021
Accepted:
January, $25^{\text {th }}, 2021$
Published online:
September, $30^{\text {th }}, 2021$

September, $30^{\text {th }}, 2021$

\begin{abstract}
Background: Complementary feeding (MPASI) is substitute meals for 6 months old child to fulfil nutritional needs that are no longer sufficient by exclusive breastfeeding. There are various factors that can influence the delivery of MPASI from maternal characteristics Purpose: The aim of this study was to examine/ to analyse the relationship between mother characteristics and provision of MPASI in children aged 0-2 years. Method: This research was a quantitative research with cross sectional design. Independent / explanatory variables included; age, level of education and occupation, and the outcome/ dependent variable was provision of complementary feeding. The population were all of 42 mothers who had children aged 0-2 years in Tlatah Village, Purwosari, Bojonegoro. The samples size from simple random sampling techniques was 38 people..Chi square test was used to analyze the correlation between dependent and independent variables. Result: There was significant relationship ( $p$ value $=0,000)$ between level of education to provision of MPASI and there were no relationship between maternal age ( $p$ value $=1,000)$ and maternal occupation ( $p$ value $=0,067$ ) to MPASI. Conclusion: There was relationship between level of education and the provision of MPASI. There were no relationship between maternal age and maternal occupation to the provision of MPASI. It can be suggested that low-educated mother should get more education and information related to complementary breastfeeding from local cadres.
\end{abstract}

Keywords : Complementary feeding; maternal age; maternal occupation; maternal educations

\section{ABSTRAK}

Latar Belakang: Makanan Pendamping Air Susu Ibu (MPASI) merupakan makanan pengganti untuk anak berusia 6 bulan dalam memenuhi kebutuhan gizi yang tak lagi cukup hanya dengan ASI Eksklusif. Ada banyak komponen yang menyebabkan pemberian tersebut oleh ibu. Tujuan: Tujuan riset ini adalah untuk meneliti/ menganalisis korelasi antara karakteristik ibu dan pemberian MPASI pada anak usia 0-2 tahun. Metode: Riset ini menggunakan riset kuantitatif bersifat analitis dengan menggunakan desain cross sectional. Variabel independen untuk ibu menggunakan umur, tingkat pendidikan dan pekerjaan ibu. Riset ini menggunakan populasi dari ibu dengan anak usia 0-2 tahun di Desa Tlatah, Purwosari, Bojonegoro sebanyak 42 orang dengan pengambilan sampel memakai teknik simple random sampling menjadi 38 orang. Uji chi square digunakan untuk menganalisis korelasi antara variabel independen dan dependen. Hasil: Terdapat hubungan signifikan ( $p$ value = $0,000)$ antara tingkat pendidikan ibu dengan pemberian MPASI dan tidak ada hubungan antara usia ibu ( $p$ value $=1,000)$ dan pekerjaan Ibu $(p$ value $=0,067)$ dengan pemberian MPASI. Kesimpulan: Ada keterkaitan tingkat pendidikan ibu dengan pemberian MPASI serta tidak ada kaitan usia serta pekerjaan yang dilakukan ibu dengan memberikan MPASI. Saran agar ibu berpendidikan rendah lebih diberikan edukasi dan informasi terkait MPASI oleh kader setempat.

Kata kunci : Makanan Pendamping ASI; Usia Ibu; Pekerjaan ibu; Pendidikan 
Resawati, et al. Maternal Characteristics and Complementary Feeding for Children Under 2 Years Old: A Correlation Study in Tlatah Village, Purwosari, Bojonegoro
JPH RECODE October 2021 ; 5 (1): 8-16 http://e-journal.unair.ac.id/JPHRECODE http://dx.doi.org/10.20473/jphrecode.v5i1.23369

\section{INTRODUCTION}

The golden period of child development can be seen from the first and second years of life. To achieve optimal growth and health status, United Nations International Children Emerging Fund (UNICEF) and World Health Organization (WHO) recommend giving infants complementary foods at 6 months old. Complementary foods are any food that contain complete nutrition given to an infant at the age of 6 months in addition to breast milk to meet the infant's optimal growth and development (Pasic et al., 2012).

Complementary food is given to prevent child growth delay, complementary foods indirectly ensure that infants obtain sufficient nutrition (Netting dan Makrides, 2017). The age of $0-2$ years is the critical period of child growth and development ((Datesfordate et al., 2017). During that period, it is necessary to introduce good eating habits in children. Regardimg the right way of complementary feeding, an infant's nutritional requirements will be fulfilled and it will meet the imbalance of overall nutrition obtained from breast milk.

Complementary feeding is recommended by WHO alongside exclusive breastfeeding. Poor complementary feeding will also affect the infant's nutritional status. Based on Bojonegoro Health Office data, the number of malnutrition among infants increased from $5.36 \%$ in 2017 to $5.39 \%$ in 2018 (Bojonegoro Health Office, 2018).

Complementary feeding was influenced by the mother's level of education and occupation where the working mother had 1.91 times chance to give complementary feeding to her child (Lestiarini \& Sulistyorini, 2020). Mother's education background in Tlatah Village is varied from primary education such as Primary School and Middle School to higher education such as High School and Undergraduate. Due to different levels of education, every mother has a certain way of giving complementary foods, including the ingredients selection. Education level significantly affects a person's ability to receive information, if a mother has lower educational background it is difficult to alter her mindset towards the newest information about complementary foods (Nurzeza et al., 2017)

Parents, especially mothers, play an important role in giving complementary foods to their children because if a mother does not comprehend the knowledge related to complementary foods, it is likely to lead to problems in the child's health and growth. Complementary foods should meet the nutrition requirements, both macronutrient and micronutrient, in quality and quantity for infants according to their age (Indonesian Pediatric Society, 2015).

There were several factors that determined the complementary feeding practice, including knowledge, education, parity, and economic factors (Mariani, N. N., 2016). Another internal determinant factor was the mother's occupation, working mothers will affect their social relations in the society and often reduce their quality time with their children (Pamarta, 2018). Thus, working mothers tend to obtain more diverse information from their neighborhoods (Lestiarini dan Sulistyorini, 2020).

Mother's age was also considered to have a correlation with complementary feeding practice. Mothers who are mature enough with some experiences will be able to achieve successful growth and development of their child, one of them is maintaining the child's health through providing sufficient nutrition from complementary feeding (Aminuddin, 2016).

Until now, there were still limited studies that examine the relationship between maternal characteristics and the complementary feeding practice in rural areas, exclusively in Tlatah Village, Purwosari District, Bojonegoro Regency, considering the lack of knowledge about the importance of giving complementary foods for child growth and development. Other than that, there were still distinctions between one research and another. Based on this explanation, the researchers were encouraged to identify the relationship between the mother's age, education level, and occupation with the complementary food selection for children aged 0-2 years in Tlatah Village, Purwosari District, Bojonegoro Regency. 
Resawati, et al. Maternal Characteristics and Complementary Feeding for Children Under 2 Years Old: A Correlation Study in Tlatah Village, Purwosari, Bojonegoro

\section{METHOD}

This research was undertaken in Tlatah Village, Bojonegoro Regency, under the Purwosari Public Health Center work area. This research was quantitative analytical research with a cross-sectional study design. It aimed to identify the relationship between the independent variables, such as the mother's characteristics (age, level of education, and occupation, with the dependent variable). The dependent variable in this study was complementary feeding practice.

This research was undertaken from December 2019 to January 2020. A total of 42 mothers whose children were aged 0-2 years in Tlatah Village, Purwosari District, Bojonegoro Regency enrolled as the research population. There were groups of mothers who gave complementary foods before their children were six months old. This was taken into account in determining the children's age range. The practice of giving mixed complementary food was also considered. Hence, it was uncertain when the exact time for those groups of mothers started giving complementary foods to their children.

The sampling technique used in this study was simple random sampling. Data was collected by undertaking interviews using a questionnaire that has been tested for validity.

A theory by Issac and Michael cited in Darmawati et al. (2017) was used to obtain the sample size. The Yamane formula was used to calculate the sample size, cited in Darmawati et al. (2017), presented as follows:
JPH RECODE October 2021 ; 5 (1): 8-16 http://e-journal.unair.ac.id/JPHRECODE http://dx.doi.org/10.20473/jphrecode.v5i1.23369

$$
n=\frac{N}{N\left(d^{2}\right)+1}
$$

Where:

$$
\begin{aligned}
& n=\text { the sample size } \\
& \mathrm{N}=\text { the population size } \\
& \mathrm{D}=\text { the acceptable sampling } \\
& \text { error }(0,05)
\end{aligned}
$$

Source : Yamane in Darmawati, et al. (2017)

$$
\begin{gathered}
n=\frac{N}{N\left(d^{2}\right)+1} \\
n=\frac{42}{42\left(0.05^{2}\right)+1} \\
n=\frac{42}{42(0.105)+1} \\
n=\frac{42}{1.105} \\
n=38
\end{gathered}
$$

The sample used was 38 people. Data analysis was undertaken using the chi-square test. Data processing was undertaken using SPSS. The primary data that has been collected was then processed using chi-square to identify the relationship between the independent and dependent variables in tabular form. This study has passed the ethical clearance from the Faculty of Nursing, Universiras Airlangga with code number 1769-KEPK.

\section{RESULT}

Table 1. The Distribution of Mother's Characteristics (Age, Level of Education, Occupation)

\begin{tabular}{lll}
\hline Research Variable & $(\mathbf{n})$ & $(\mathbf{\% )}$ \\
\hline Age: & & \\
<40 Years & 32 & 84.21 \\
>40 Years & 6 & 15.79 \\
\hline Level of Education: & & \\
Primary education & 27 & 71.05 \\
Higher education & 11 & 28.95 \\
\hline Occupation: & & \\
Employed & 21 & 55.26 \\
Unemployed & 17 & 44.74 \\
\hline
\end{tabular}


Resawati, et al. Maternal Characteristics and Complementary Feeding for Children Under 2 Years Old: A Correlation Study in Tlatah Village, Purwosari, Bojonegoro

Table 1 showed the research variable distribution. As shown in Table 1, the characteristics of 38 respondents were described into three categories: age, level of education, and occupation.

Of 38 respondents, the majority of the mothers were aged $<40$ years $(84.21 \%)$. Meanwhile, the mothers $>40$ years were $15.79 \%$
Based on the level of education, $71.05 \%$ of theirs was primary education, while those who possess a higher level of education were $28.95 \%$. According to characteristics based on occupation, the majority were employed $(55.26 \%)$, and $44.74 \%$ of them were unemployed.

Table 2. The Distribution of Complementary Feeding among Children Aged 0-2 Years

\begin{tabular}{llll}
\hline $\begin{array}{l}\text { Research } \\
\text { Variable }\end{array}$ & Category & (n) & \% \\
\hline Complementary & Provide & 55.26 \\
Feeding & 21 & \\
& $\begin{array}{l}\text { Complementary } \\
\text { Feeding }\end{array}$ & & 44.74 \\
\cline { 2 - 4 } & $\begin{array}{l}\text { Do Not Provide } \\
\text { Complementary }\end{array}$ & 17 & \\
\hline Feeding & 38 & 100 \\
\hline
\end{tabular}

Complementary feeding practice distribution among children aged 0-2 years showed that more than half $(55.26 \%)$ of the respondents provided complementary food for their children. While the ones who did not provide complementary food to their children were

$44.74 \%$.

Table 3. Relationship between Mother's Characteristics and Complementary Feeding Practice

Mother's

Characteristics

\section{Category}

\begin{tabular}{|c|c|c|c|c|c|c|c|}
\hline \multirow{3}{*}{$\begin{array}{l}\text { Mother's } \\
\text { Characteristics }\end{array}$} & \multirow[t]{3}{*}{ Category } & \multicolumn{4}{|c|}{ Complementary Feeding Practice } & \multirow{3}{*}{$\begin{array}{l}P- \\
\text { value }\end{array}$} & \multirow[t]{3}{*}{ OR $95 \% \mathrm{CI}$} \\
\hline & & \multicolumn{2}{|c|}{$\begin{array}{l}\text { Provide } \\
\text { Complementary } \\
\text { Feeding }\end{array}$} & \multicolumn{2}{|c|}{$\begin{array}{l}\text { Do Not Provide } \\
\text { Complementary } \\
\text { Feeding }\end{array}$} & & \\
\hline & & (n) & $\%$ & (n) & $\%$ & & \\
\hline \multirow[t]{2}{*}{ Age } & $<40$ Years & 18 & 47.37 & 14 & 36.84 & \multirow[t]{2}{*}{1.000} & \multirow{2}{*}{$\begin{array}{c}0.961(0.725- \\
1.272)\end{array}$} \\
\hline & $>40$ Years & 3 & 7.89 & 3 & 7.89 & & \\
\hline \multirow{2}{*}{$\begin{array}{l}\text { Level of } \\
\text { Education }\end{array}$} & Low & 10 & 26.32 & 17 & 44.74 & \multirow[t]{2}{*}{0.000} & \multirow{2}{*}{$\begin{array}{c}2.100(1.341- \\
3.289)\end{array}$} \\
\hline & High & 11 & 28.95 & 0 & 0 & & \\
\hline \multirow[t]{2}{*}{ Occupation } & Employed & 12 & 31.58 & 9 & 23.68 & \multirow[t]{2}{*}{0.067} & \multirow{2}{*}{$\begin{array}{c}0.926(0.518- \\
1.657)\end{array}$} \\
\hline & Unemploye & 9 & 23.68 & 8 & 21.05 & & \\
\hline
\end{tabular}

$P$ value

\section{OR $95 \% \mathrm{CI}$}

Table 3 showed that more respondents practiced complementary feeding than those who did not with the ratio of $47.37 \%$ to $7.89 \%$, the majority of whom were mothers whose age were under 40 years.

Mothers whose age was under 40 years who did not provide complementary food were
$36.84 \%$ and the ones whose age was $>40$ years who did not provide complementary food were $7.89 \%$. The result of the chi-square test showed that the $\mathrm{p}$-value $=0.560$ or $\mathrm{p}>a(0.05)$, thus $\mathrm{H}_{0}$ was accepted and $\mathrm{H}_{1}$ was rejected or there the mother's age was not significantly correlated with complementary feeding 
Resawati, et al. Maternal Characteristics and Complementary Feeding for Children Under 2 Years Old: A Correlation Study in Tlatah Village, Purwosari, Bojonegoro

practice in Tlatah Village, Purwosari District, Bojonegoro Regency.

The proportion of those who did not practice complementary feeding was higher among mothers with primary education level (44.74\%) compared to those with higher education level $(0 \%)$. Means that there were no mothers with higher education level who did not practice complementary feeding to their children. Meanwhile, the percentage of complementary feeding was higher among mothers who had a higher education level (28.95\%) compared to mothers who had a lower education level (26.32\%). The result of the chi-square test showed that the $\mathrm{p}$ value $=0.000$ or $\mathrm{p}>\mathrm{a}(0.05)$, thus $\mathrm{H} 0$ was rejected and $\mathrm{H} 1$ was accepted. This result indicated that there was a correlation between the mother's educational level and complementary feeding practice in Tlatah Village, Purwosari District, Bojonegoro Regency.

Mothers with an occupation were more likely to practice complementary feeding (31.58\%) compared to mothers who were not working (23.68\%). Mothers who had occupation but did not practice complementary feeding were $23.68 \%$ of the respondent, while the mothers who were not working were $21.05 \%$. The result of the chi-square test showed that the $\mathrm{p}$-value $=0.527$ or $\mathrm{p}>\mathrm{a}(0,05)$, hence $\mathrm{H} 0$ was accepted and $\mathrm{H} 1$ was rejected. This represented that there was no correlation between the mother's occupation with complementary feeding practice in Tlatah Village, Purwosari District, Bojonegoro Regency.

The pooled data showed that the level of education variable had a significant correlation with the practice of complementary feeding among children aged 0-2 years in Tlatah Village, Purwosari District, Bojonegoro Regency, with $(\mathrm{p}=0.000 ; \quad \mathrm{OR}=2.100$ CI $=1.341-3.289)$. It indicated that mothers with lower education level (Primary School to Middle School) had 2.100 likelihood of not undertaking complementary feeding. Meanwhile, the other two variables had no significant correlation with the implementation of complementary feeding.
JPH RECODE October 2021; 5 (1): 8-16 http://e-journal.unair.ac.id/JPHRECODE http://dx.doi.org/10.20473/jphrecode.v5i1.23369

DISCUSSION

Correlation between Mother's Age and Complementary Feeding Practice among Children Aged 0-2 Years

Based on the chi-square test result, there was no relationship between age and complementary feeding, and the mother's age was not significantly correlated with the complementary feeding practice among children aged 0-2 years. The groups who had a higher likelihood to practice complementary feeding were the mother whose age was $<40$ years compared to those whose age was $>40$ years.

Age characteristic reflects someone's behavior. The influence of age can be seen from a person's ability and maturity in digesting and storing information (Notoatmodjo, 2012). However, the age factor can not always be used as a standard to observe something, for example, it is not necessarily someone older knows more about complementary feeding than someone whose age is younger. The pooled data showed that there was no correlation between mother's age and complementary feeding practice among children aged 0-2 years, this result was similar to a study by Usmiyati and Maulida (2017) as well Juliyandri, Suyatno, and Mawarni (2018).

A theory by Notoatmodjo was different from the result of this research, it was proved that the factor that made this happen was the ease of access to information in the era of the industrial revolution. Mothers aged $<40$ years or relatively young had easier access to information from various sources such as the internet or e-book despite the might lack experience compared to mothers aged 40 years and above (Usmiyati dan Maulida, 2017).

Mother's age variable was not significantly associated with complementary feeding practice as the majority of mothers in Tlatah Village were young mothers, thus the information exchange was spread quickly. Even though young mothers were likely to have less experience and knowledge, yet they received plenty of information from other mothers of their age. The health workers in Tlatah Village were commonly young mothers aged $<40$ years. Therefore, the information was shared easily as there was no age gap.

The result of this study was different from a study reported (Aminuddin, 2016) that the mother's age correlated with the practice of complementary feeding. Mother's maturity 
Resawati, et al. Maternal Characteristics and Complementary Feeding for Children Under 2 Years Old: A Correlation Study in Tlatah Village, Purwosari, Bojonegoro

was in line with their experiences and knowledge they had. Matured age made mothers enable to prevent their children from any disease, one of which was by practicing good complementary feeding.

Correlation between Mother's Level of Education and Complementary Feeding Practice among Children Aged 0-2 Years

This study found that level of education was correlated with the complementary feeding practice and there was a significant relationship between education level and complementary feeding practice among children aged 0-2 years. The chi-square test result stated that the number of complementary feeding to children aged 0-2 years was higher among mothers who had higher education levels in comparison to mothers who had lower education levels. This result indicated that the level of education was related to the practice of complementary feeding among children aged 0-2 years.

Education supports mothers to receive various information regarding child growth and health, such as providing complementary food at 6 months of age. High-educated mothers will easily digest the information they received that can be applied to their children's development (Nababan dan Widyaningsih, 2018).

A similar finding has also been reported by Arifin et al. (2020) that the mother's level of education was one of the main factors that determined complementary feeding practice among children. Mothers who had a high level of education were likely to give orders to their children and absorb valuable information such as parenting models, how to educate children, as well to protect them from disease and danger. In the term of complementary feeding practice, high educated mothers will get various knowledge that can be used as a reference in planning food menus, how to eat and fulfill children's nutrition.

The odds of mothers with lower education did not practice complementary feeding was higher compared to mothers with higher education levels. It was due to mothers with lower education levels obtained only information regarding a balanced diet during their education life, therefore it caused them not to receive any information related to child development (Barati et al., 2018).

This finding was in agreement with the findings of another study by Widiastuti et al.
JPH RECODE October 2021; 5 (1): 8-16 http://e-journal.unair.ac.id/JPHRECODE http://dx.doi.org/10.20473/jphrecode.v5i1.23369

(2020) that explained there was a relationship between the mother's education level and complementary feeding practice. Someone's educational experiences affect their understanding in obtaining information. Education will make a person look for useful information such as their baby's development. Educated mothers tend to explore and receive information quickly.

Reagarding education as a factor of complementary feeding practice, the majority of mothers in Tlatah Village had a health education background. This group of mothers had already a good foundation during the time they spent at school, therefore they implemented the knowledge that they received in the family and even further improved their skills through counseling programs. Mothers with high education levels tend to have a higher concern for their children's growth and health.

However, this finding was in contrast to a study by Laraswati and Siti (2019) which stated that there was no relationship between mother's education level and complementary feeding practice among children. It was interview-based research that showed that there were still many highly educated mothers who did not get enough knowledge regarding complementary feeding practice. There were also highly educated mothers who had adequate information, yet did not implement their knowledge to carry out complementary feeding practices for their children. Education helps someone to gain information quickly. Mothers who actively listening or watching and seeking further information about complementary feeding will give complementary food to their children regardless of their education level. It is because the mothers understand the benefits of complementary feeding.

\section{Correlation between Mother's Occupation and Complementary Feeding Practice among Children Aged 0-2 Years}

This study found that mother's occupation had no relationship with complementary feeding practice, and there was no significant correlation between mother's occupation and the practice of complementary feeding among children aged 0-2 years.

Mothers with an occupation were more likely to practice complementary feeding compared to mothers who were not working. Therefore, there was no association between 
Resawati, et al. Maternal Characteristics and Complementary Feeding for Children Under 2 Years Old: A Correlation Study in Tlatah Village, Purwosari, Bojonegoro

the mother's occupation and complementary feeding. Other research supported the result of this study which reported that regardless of the mother's occupational status, it had the same odds to not practice complementary feeding to their children. Despite the fact that mothers who were not working had a higher chance to provide complementary food.

Mother's activities to earn funds and sustain their children's life play a major role in the practice of complementary feeding. Children's food and drink intake are influenced by their mother's activities. Mothers who are not working tend to have extra time than working mothers in providing nutritious food based on their age and what they need (Casnuri et al., 2017).

Complementary feeding is more likely practiced by working mothers compared to non-working mothers is also due to the uneven food availability. This condition is caused by the family socio-economic conditions which affect the consumption paradigm which in turn affects what the child consumes. Greater income to fulfill everyday needs tends to come from working mothers (Suhardjo, 2005).

Contrary to this result, a study done by Yanthi and Masruroh (2018) showed that the mother's occupation correlated with the complementary feeding practice. The result stated that non-working mothers had more free time and access to information regarding complementary feeding thus there would be more non-working mothers who practiced complementary feeding for their children. Another factor that supported this result was working mothers barely had time and opportunity to give care for their children. Working mothers seldom come to any counseling events organized by health workers hence they do not obtain information and knowledge about complementary feeding (Anwar dan Ulfa, 2019).

According to the researcher, the absence of the correlation between mother's occupation and complementary feeding practice was because many working mothers were employees of Public Health Centers and Regional Public Hospitals. Mothers who work in the health field are always exposed to various information about health, especially the children's growth and health, therefore they have a higher chance to give complementary foods.
JPH RECODE October 2021; 5 (1): 8-16 http://e-journal.unair.ac.id/JPHRECODE http://dx.doi.org/10.20473/jphrecode.v5i1.23369

The results of this study were limited, this study has not explored further other factors other than the mother's characteristics, namely environmental factors, family, culture, belief, etc. However, this study has been able to determine the correlation between maternal characteristics and complementary feeding practice among children aged $0-2$ years in Tlatah Village, Purwosari District, Bojonegoro Regency. It is expected that this research increase the awareness of health workers and other communities in general on the importance of sharing knowledge and information, especially regarding complementary feeding practice hence the children can grow and develop in a healthy with sufficient nutrition.

\section{CONCLUSION}

According to the result of this research, it can be concluded that there was a correlation between mother's level of education and complementary feeding practice. However, the other two variables, mother's age and occupation, were not significantly correlated with the complementary feeding practice among children aged 0-2 years in Tlatah Village, Purwosari District, Bojonegoro Regency.

\section{SUGGESTION}

Future researchers are expected to examine more variables such as attitude and behavior. Future researchers can also take a wider and varied sample so that the obtained result will be more accurate or determine the relationship between this research and the incidence of a certain disease. It is expected that the result of this research can increase community awareness, especially in rural areas, regarding the importance of practicing complementary feeding to their children.

\section{ACKNOWLEDGEMENTS}

The authors would like to acknowledge the help of friends during the data collection process, as well as to Public Health Faculty of Airlangga University which has allowed conducting this research.

\section{REFERENCE}

Abdoerrachman, M. H. (1998) Pertumbuhan dan Perkembangan dalam buku kuliah ilmu kesehatan Anak, jilid 1. Jakarta: Bagian Ilmu Kesehatan Anak Fakultas 
Resawati, et al. Maternal Characteristics and Complementary Feeding for Children Under 2 Years Old: A Correlation Study in Tlatah Village, Purwosari, Bojonegoro

Kedokteran Universitas Indonesia.

Anwar, C. and Ulfa, Z. (2019) 'Hubungan Pengetahuan dan Status Pekerjaan Ibu dengan Pemberian MP-ASI pada Bayi Usia 7-12 Bulan di Wilayah Kerja Puskesmas Batoh Banda Aceh Tahun 2018', Journal of Healthcare Technology and Medicine, 4(1), p. 29. doi: 10.33143/jhtm.v4i1.164.

Arifin, Y., Syofiah, P., Hesti, N. (2020) 'Keluarga Dengan Pemberian Mp-Asi Pada Balita', Jurnal Human Care, 5(3), pp. 836-844.

Barati, Z. et al. (2018) 'Breastfeeding and complementary feeding practices among children living in a rice surplus area, Central Java, Indonesia', Nutrition and Food Science, 48(4), pp. 589-604. doi: 10.1108/NFS-07-20170144.

Casnuri, C. Wijayanti, H., Roliyah, D. (2017)

'HUBUNGAN

TINGKAT

PENGETAHUAN IBU TENTANG MP-ASI DENGAN PERILAKU PEMBERIAN MP-ASI PADA BALITA USIA 6-24 BULAN DI PUSKESMAS MERGANGSAN YOGYAKARTA', The Shine Cahaya Dunia Kebidanan, Vol 2, No.

Dinas Kesehatan Kabupaten Bojonegoro (2018) 'Profil Kesehatan Kabupaten Bojonegoro', (0353), p. 100.

Heryanto, E. (2017) 'Faktor-Faktor yang Berhubungan dengan Pemberian Makanan Pendamping ASI Dini', Jurnal Aisyah: Jurnal Ilmu Kesehatan, 2(2), pp. 141-152. doi: 10.30604/jika.v2i2.56.

IDAI (2015) Praktik Pemberian Makanan Berbasis Bukti pada Bayi dan Batita di Indonesia untuk mencegah Malnutrisi. Jakarta.

Juliyandari, A., Suyatno. Mawarni., A. (2018) 'Hubungan Karakteristik Ibu Dan Perilaku Dalam Pemberian Mp-Asi Dini Dengan Pertumbuhan Bayi Usia 0-6 Bulan(Studi Di Wilayah Kerja Puskesmas Poncol Kota Semarang Tahun 2017)', Jurnal Kesehatan Masyarakat (e-Journal), 6(4), pp. 247-254.

Laraswanti, Siti., M. (2019) 'MAKANAN PENDAMPING ASI PADA BAYI BERUMUR $0-6$ BULAN CHARACTERISTIC OF THE
JPH RECODE October 2021; 5 (1): 8-16 http://e-journal.unair.ac.id/JPHRECODE http://dx.doi.org/10.20473/jphrecode.v5i1.23369

MOTHERS THAT GIVE DISHES BREASTFEEDING ON THE BABY WAS 0-6 MONTHS', 1, pp. 93-97.

Lestiarini, S. and Sulistyorini, Y. (2020) 'Perilaku Ibu pada Pemberian Makanan Pendamping ASI (MPASI) di Kelurahan Pegirian', Jurnal PROMKES, 8(1), p. 1. doi: 10.20473/jpk.v8.i1.2020.1-11.

Mariani, N. N., h. H. dan G. S. N. (2016) 'Faktor-Faktor Yang Berhubungan Dengan Pemberian Mp-Asi Dini Di Wilayah Kerja Uptd Puskesmas Sindanglaut Kecamatan Lemahabang Kabupaten Cirebon', Jurnal Kesehatan, 7(3), pp. 420-426.

Nababan, L. and Widyaningsih, S. (2018) 'Pemberian MPASI dini pada bayi ditinjau dari pendidikan dan pengetahuan ibu', Jurnal Keperawatan dan Kebidanan Aisyiyah, 14(1), pp. 32-39. Available at: http://dx.doi.org/10.31101/jkk.547.

Netting, M. J. and Makrides, M. (2017) 'Complementary foods: Guidelines and practices', Nestle Nutrition Institute Workshop Series, 87, pp. 112. doi: 10.1159/000449497.

Notoatmodjo, S. (2012) Promosi Kesehatan \& Ilmu Perilaku, Jakarta: Rineka Cipta.

Nurzeza, A., Larasati and Wulan, D. (2017) 'Hubungan Tingkat Pendidikan , Pengetahuan dan Kepercayaan Ibu terhadap Pemberian Makanan Pendamping ASI ( MP - ASI ) pada Bayi di Bawah Usia 6 Bulan di Desa Braja Sakti , Kecamatan Way Jepara, Kabupaten Lampung Timur', $J$ Agromedicine, 4, pp. 0-6.

Suhardjo (2005) Perencanaan Pangan dan Gizi. Jakarta.

Usmiyati, U. and Maulida, I. (2017) 'Analisis Perilaku Ibu Dalam Pemberian Mp-Asi Secara Dini Menurut Faktor Penyebabnya Pada Bayi Di Puskesmas Margadana Kota Tegal Tahun 2015', Siklus : Journal Research Midwifery Politeknik Tegal, 6(1), pp. 176-180. doi: 10.30591/siklus.v6i1.468.

Wahyuhandani, E. and Mahmudiono, T. (2017) 'Hubungan Pengetahuan Gizi dan Pekerjaan Ibu Terhadap Pemberian MP-ASI Dini di Puskesmas Telaga Biru Kota Pontianak Tahun 2014', Amerta Nutrition, 1(4), p. 300. 
Resawati, et al. Maternal Characteristics and

Complementary Feeding for Children Under 2 Years Old: A Correlation Study in Tlatah Village, Purwosari,

Bojonegoro

doi: 10.20473/amnt.v1i4.7142.

Widiastuti, S. W., Marini, M. and Yanuar, A. (2020) 'Hubungan Pendidikan, Pengetahuan Dan Budaya Terhadap Pemberian Makanan Pendamping Asi Dini Di Puskesmas Ciruas Kabupaten Serang Tahun 2019', Journal Educational of Nursing(Jen), 3(1), pp. 1-10. doi: 10.37430/jen.v3i1.55.
JPH RECODE October 2021; 5 (1): 8-16

http://e-journal.unair.ac.id/JPHRECODE

http://dx.doi.org/10.20473/jphrecode.v5i1.23369

Yanthi, N., Masruroh, M. (2018) 'PENGETAHUAN DAN

PEKERJAAN IBU BERHUBUNGAN DENGAN PEMBERIAN MP-ASI

DINI DI DESA NGAMPIN

WILAYAH KERJA PUSKESMAS AMBARAWA', Jurnal SIKLUS, 07, pp. 315-32 